\title{
A Histological Study of Ovarian Development in the Giant Red Shrimp Aristaeomorpha foliacea (Crustacea: Decapoda: Aristeidae) from the Southern Tyrrhenian Sea (Western Mediterranean)
}

\author{
Anna Perdichizzi, ${ }^{1}$ Laura Pirrera, ${ }^{1}$ Valeria Micale, ${ }^{1}$ Ugo Muglia, ${ }^{2}$ and Paola Rinelli1 \\ ${ }^{1}$ National Research Council, Institute for Coastal Marine Environment (IAMC-CNR), Spianata S. Raineri 86, 98122 Messina, Italy \\ ${ }^{2}$ Department of Morphology, Biochemistry, Physiology and Animal Production, Faculty of Veterinary Medicine, University of Messina, \\ Polo Universitario Annunziata, 98168 Messina, Italy
}

Correspondence should be addressed to Anna Perdichizzi, anna.perdichizzi@iamc.cnr.it

Received 20 October 2011; Accepted 5 December 2011

Academic Editors: K. Kapiris and L. Zeng

Copyright (C) 2012 Anna Perdichizzi et al. This is an open access article distributed under the Creative Commons Attribution License, which permits unrestricted use, distribution, and reproduction in any medium, provided the original work is properly cited.

\begin{abstract}
The reproductive features of the giant red shrimp, Aristaeomorpha foliacea, were investigated in the southern Tyrrhenian sea by experimental trawl sampling. The annual length-frequency distribution showed a multimodal trend in females, ranging between 16 and $67 \mathrm{~mm}$ carapace length (CL), and a unimodal trend in males (18-45 $\mathrm{mm} \mathrm{CL})$. Mature males occurred in different proportions all year round, while females displayed seasonal maturity (June-September), with a peak in July. Six oocyte developmental stages were identified, the most advanced of which ( $\mathrm{Pv}$, postvitellogenic) had never been described before in this species. Ovary development followed a group-synchronous pattern, with the yolked oocyte stock clearly separated from the reservoir of unyolked oocytes, suggesting that $A$. foliacea is a total spawner, with determinate fecundity. Based upon histological findings, a revision of macroscopic maturity staging employed in Mediterranean bottom trawl surveys (MEDITS) is proposed.
\end{abstract}

\section{Introduction}

The giant red shrimp Aristaeomorpha foliacea (Risso, 1827) (Decapoda, Aristeidae) is a widespread decapod crustacean in the eastern and western Atlantic, western Pacific, the Indian Ocean, as well as the Mediterranean Sea, showing a preference for muddy bottoms, with aggregation mainly in submarine trenches and canyons along the continental slope from $150 \mathrm{~m}$ to $1850 \mathrm{~m}$ with a peak in abundance between $300 \mathrm{~m}$ and $700 \mathrm{~m}[1,2]$.

Together with the other red shrimp Aristeus antennatus (Risso, 1816), A. foliacea represents an important target species of commercial fleet fishing off the southern Tyrrhenian Sea operating over the continental slope, with total landings of the order of one hundred tons [3]. Because of its economic value, many studies have been carried out on the biology, population ecology, and fisheries of this shrimp [4-13].
Reproductive biology is one of the main concerns in formulating proper management practices for fishery science. In fact, the relationship between size and reproduction events, such as mating and sexual maturity, is crucial to understand the dynamics of a stock. Knowledge of reproductive biology of A. foliacea has mainly come from studies on ovary maturation of fresh specimens by means of macroscopical investigations [10, 13-19].

On the other hand, few studies examined histology of ovarian development [20-23], and many aspects, such as the spawning pattern and type of fecundity, remain to be solved. International commissions for fisheries study (i.e., ICES, International Council for the Exploration of the Sea, GFCM, General Fisheries Council for the Mediterranean) strongly recommend standardizing criteria for evaluating sexual maturity in target species. Recently, the need for a common system for classification of maturity stages in Crustaceans has 


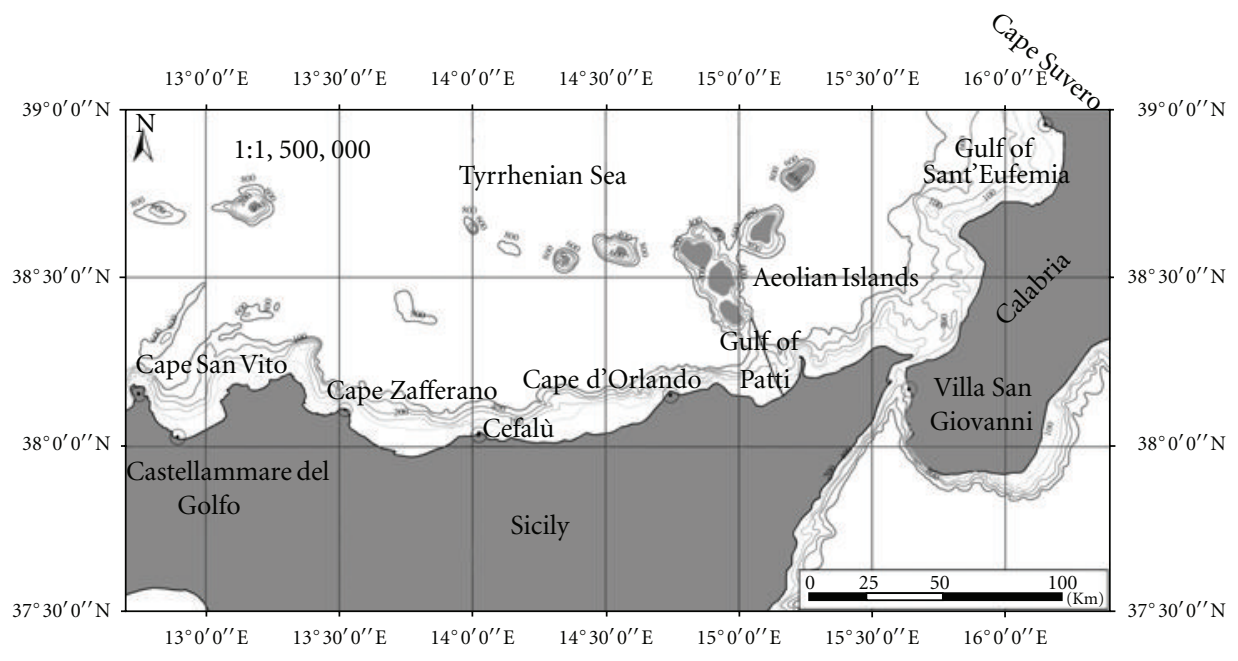

Figure 1: Sampling area.

been highlighted by an Expert Group of ICES (2010), which also pointed out the importance of histology as a tool for obtaining the highest accuracy in these studies.

This paper describes for the first time some reproductive features of A. foliacea caught in the southern Tyrrhenian Sea, such as monthly maturity stages by size and length structures by maturity stage. Moreover histological analyses of ovaries were performed in order to validate the empirical, macroscopic scale used in experimental trawl surveys through a detailed description of maturity stages based upon oocyte development. The information provided by this paper is intended to contribute to establishing production and population dynamics models, for a rational exploitation of this important fishery resource.

\section{Material and Methods}

2.1. Biological Data and Reproductive Parameters. Red shrimps were caught on a monthly basis (September 2008 through August 2009) by commercial trawlers operating in the southern Tyrrhenian Sea, between the Gulf of Patti and Aeolian Islands, in a depth range from 500 to 700 metres (Figure 1). The sampling was conducted in order to sample all stages of maturity. Specimens $(n=21163)$ were sexed and measured for carapace length $(\mathrm{CL})$ to the nearest of $0.01 \mathrm{~mm}$. The overall length frequency distributions (LFDs) of males and females for all year were estimated. The differences between the two sexes were tested by Kolmogorov-Smirnov test $(P \leq 0.001)$. Body weight (BW) was recorded to the nearest $0.01 \mathrm{~g}$. Gonad weight (GW) of females was recorded to the nearest $0.001 \mathrm{~g}$, and gonadosomatic index (GSI) was estimated as $(\mathrm{GW} / \mathrm{BW}) \times 100$.

On the basis of the colour and shape of the ovary and testis, each specimen was classified according to the macroscopic maturity scale adopted in MEDITS programme (Table 1). Males maturity was checked by the presence of the spermatophores in the terminal ampoullae of vasa deferentia. Presence or absence of spermatophores in the thelycum of females (inseminated specimens) was also recorded.
The length structures by maturity stage were estimated by analyzing the box-plot representation. Statistical differences between maturity stages and carapace length were tested by Kruskal-Wallis test $(P \leq 0.001)$.

2.2. Ovarian Histology. At least 10 females of each maturity stage were fixed on board in $10 \%$ neutral formalin, after cutting the integument. Once in the laboratory, after washing in running tap water for 4 hours, ovaries were dissected, dehydrated in a graded series of ethanol, embedded in resin, and cut in $5 \mu \mathrm{m}$ thick sections. Sections were stained with haematoxylin-eosin and observed under a light microscope for histological description of oocyte development and ovarian maturation. Oocyte size was estimated by the imaging software Leica IM1000 v 1.20, by taking the average between the major and minor axis in rounded oocytes, and by measuring the major axis (length) of rectangular oocytes, for the sake of comparison with previous studies [23].

\section{Results}

3.1. Population Structure. The population structure of females and males is presented in Figure 2. The size of females ranged from 16 to $67 \mathrm{~mm} \mathrm{CL}$, showing a multimodal trend during the year. The most abundant individuals had carapace length generally between 27 and $30 \mathrm{~mm}$.

The males measured between 18 and $45 \mathrm{~mm} \mathrm{CL}$ and exhibited a unimodal distribution. A significant difference in LFD between males and females was found $(P<0.001)$.

3.2. Gonadal Maturation. Females of Aristaeomorpha foliacea displayed seasonal maturity. Ovarian maturation started in April (stage $2 \mathrm{c}=8 \%$ ). Mature females (stage $2 \mathrm{~d}$ ) were found from June through September, with a peak value in July $(2 \mathrm{~d}$ $=38 \%$ ) (Figure 3(a)). Spent individuals appeared in August (20.1\%) and September (21.3\%). Females with stages 2a (developing virgin) and 2b (recovering) ovaries were present 
TABLE 1: Macroscopic maturity scale adopted in MEDITS trawl surveys (MEDITS Instruction Manual v.5.0, 2008).

\begin{tabular}{|c|c|c|c|c|}
\hline Sex & Reproductive apparatus aspect & Colouring of fresh ovary & Maturation state & Stage \\
\hline $\mathrm{U}$ & $\begin{array}{l}\text { Sex not distinguished by naked eye. } \\
\text { Sex undetermined }\end{array}$ & translucid & Undetermined & 0 \\
\hline $\mathrm{F}$ & $\begin{array}{l}\text { Ovary hardy visible in transparence. After dissection of } \\
\text { the tegument ovary is small and lobes are flaccid, } \\
\text { stringy and poorly developed. No sphermatophores on } \\
\text { thelycum. }\end{array}$ & Whitish or translucid & Immature = virgin $*$ & 1 \\
\hline M & $\begin{array}{l}\text { Petasma is not much visible, and there is not spermatic } \\
\text { masses (emi-spermatophores) on the seminal } \\
\text { ampullae, located on side of the } \mathrm{V} \text { pair of pereiopods. } \\
\text { Long rostrum. }\end{array}$ & & & \\
\hline $\mathrm{F}$ & $\begin{array}{l}\text { Ovary status to develop. Cephalic and lateral lobes are } \\
\text { small but distinguishable with the naked eye. } \\
\text { Abdominal extension are thin and just visible. }\end{array}$ & Flesh coloured & Virgin developing** & $2 \mathrm{a}$ \\
\hline M & $\begin{array}{l}\text { Petasma appears visible and nearly or completely } \\
\text { joined, but there are no spermatic masses in the } \\
\text { seminar ampullae. Long or intermediate rostrum. }\end{array}$ & & & \\
\hline $\mathrm{F}$ & $\begin{array}{l}\text { Ovary status to redevelop. Cephalic and lateral lobes are } \\
\text { small but distinguishable by naked eye. } \\
\text { Abdominal extension is thin and just visible. } \\
\text { Occasionally presence of spermatophores. }\end{array}$ & Flesh coloured & Recovering** & $2 b$ \\
\hline M & $\begin{array}{l}\text { Petasma appears completely joined, but there are no } \\
\text { spermatic masses in the seminar ampullae. Short } \\
\text { rostrum. }\end{array}$ & & & \\
\hline $\begin{array}{l}\mathrm{F} \\
\mathrm{M}\end{array}$ & $\begin{array}{l}\text { Ovary developed and occupies almost entirely the } \\
\text { dorsal portion. The cephalic and lateral lobes are much } \\
\text { developed and have a turgid consistence. }\end{array}$ & Light and dark grey & $\begin{array}{l}\text { Maturing or almost } \\
\text { mature }\end{array}$ & $2 c$ \\
\hline $\mathrm{F}$ & $\begin{array}{l}\text { Turgid ovary extends to the whole dorsal portion, } \\
\text { covering the organs below. Lobes and extensions well } \\
\text { developed, in particular the abdominal extension is } \\
\text { much evident. Oocytes well visible. }\end{array}$ & Black & Mature & $2 \mathrm{~d}$ \\
\hline M & $\begin{array}{l}\text { Petasma is perfectly visible and completely joined. } \\
\text { Spermatic masses in seminar ampullae. Small rostrum. }\end{array}$ & & & \\
\hline $\mathrm{F}$ & Resting ovary. Presence of spermatophores. & Uncoloured & Resting adult* & $2 \mathrm{e}$ \\
\hline
\end{tabular}

Adult specimens.

$*^{*}, * *$ Warning! Be careful. These stages could be confused with each other.

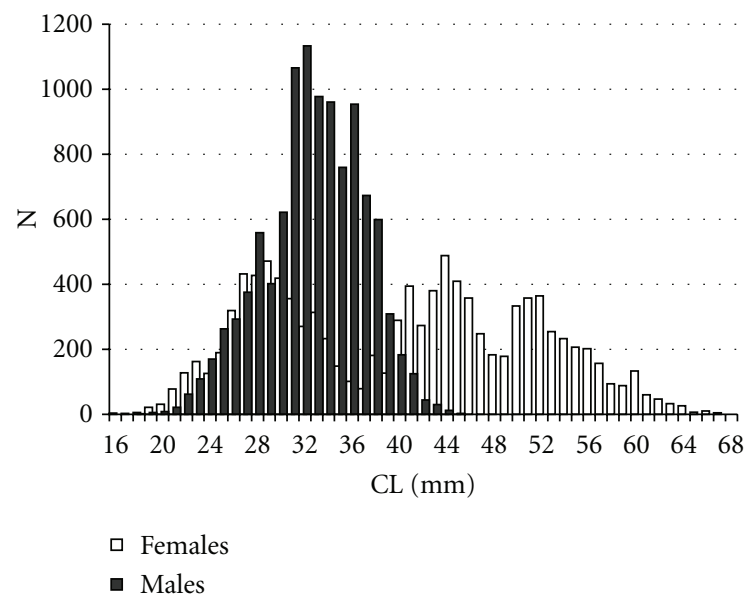

Figure 2: Length frequency distributions (LFDs) of females and males of Aristaeomorpha foliacea caught in the southern Tyrrhenian Sea. throughout the year, while specimens with immature ovaries (stage 1) were caught from February to September.

The smallest female with mature ovaries (stage $2 \mathrm{~d}$ ) was observed in July and measured $41 \mathrm{~mm}$ CL. Only larger females (CL range: $41-66 \mathrm{~mm}$ ) contributed to the reproductive pool, which, taking into consideration both maturing (2c) and mature (2d) specimens, represented about $50 \%$ of total during the spawning peak.

The occurrence of reproductive males of $A$. foliacea, characterized by the presence of spermatophores in the terminal ampullae, was constant and very high during the whole sampling period, with values ranging from $59 \%$ to $100 \%$ (Figure $3(\mathrm{~b}))$. The size range of mature males ranged from 25 to $45 \mathrm{~mm}$ CL.

The size at maturity stage analysis, made on all combined months, indicated, for both sexes, a satisfactory resolution capability of the adopted scale. For females the 2a stage prevailed (36.7\%) while for males the $2 \mathrm{~d}$ stage prevailed $(90.4 \%)$ (Table 2). 


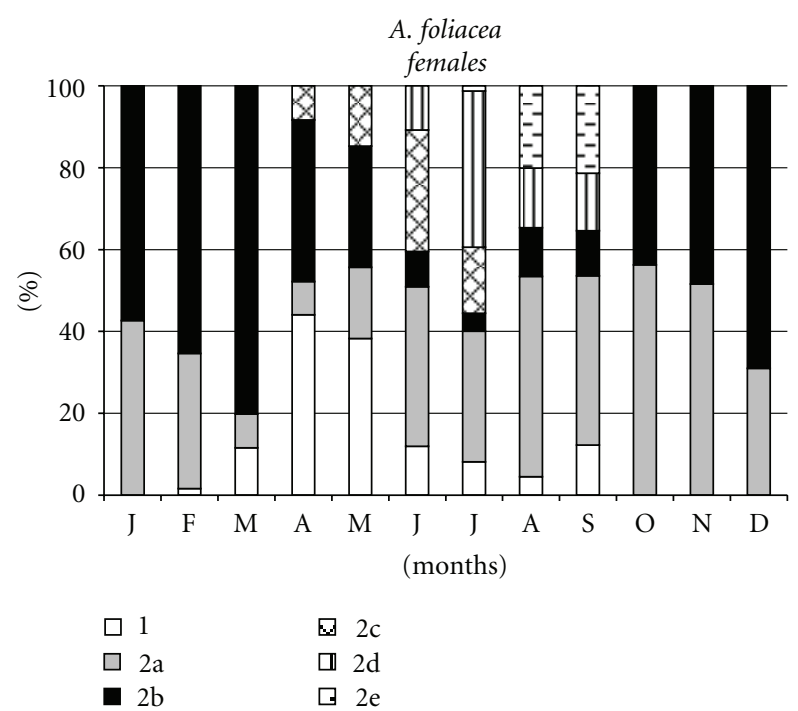

(a)

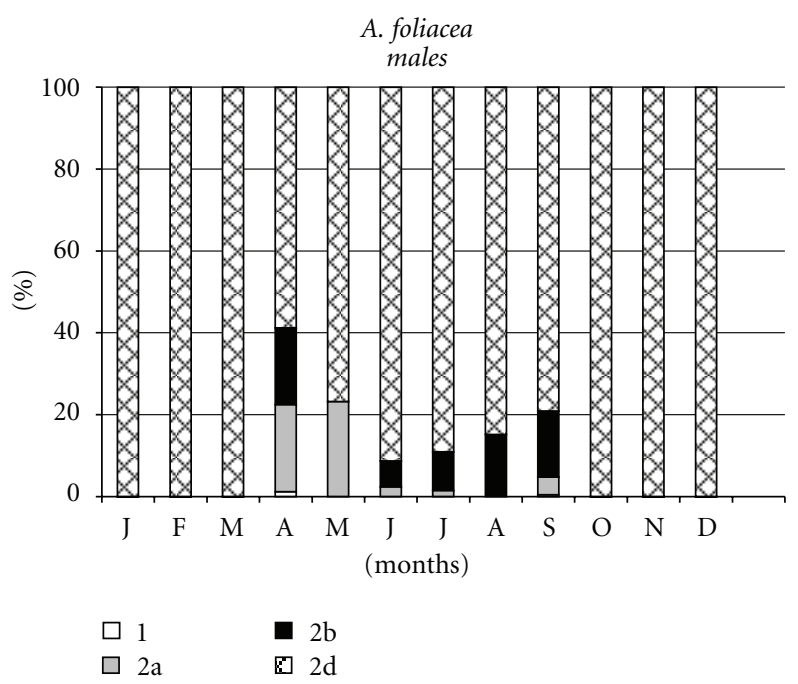

(b)

FIGURE 3: Monthly occurrence of ovarian maturity stages of females (a) and males (b) of Aristaeomorpha foliacea from the southern Tyrrhenian Sea.

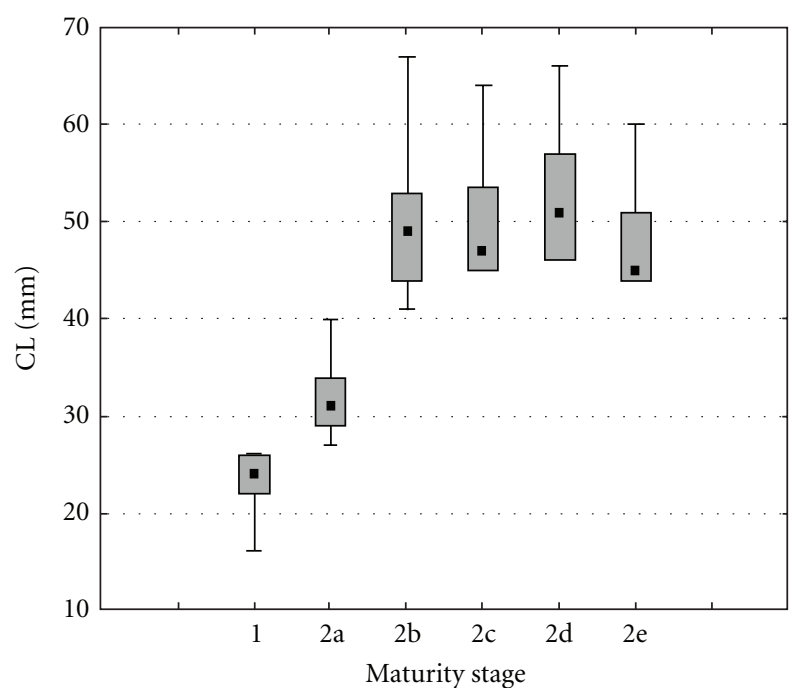

- Median

$25 \%-75 \%$

I Min-max

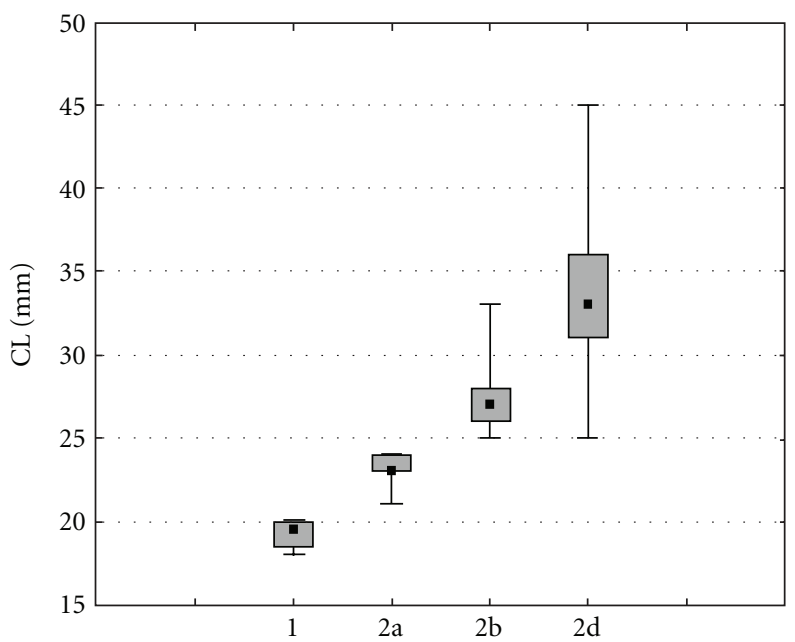

- Median

$25 \%-75 \%$

I Min-max

(a)

(b)

Figure 4: Overall (all months combined) box-plot representation of length structure by sex (females, (a) and males, (b)) and maturity stage in Aristaeomorpha foliacea.

Relation between median and maturity stages showed significant differences for both sexes $(P<0.001)$, except between stages $2 \mathrm{~b}$ and $2 \mathrm{c}(P=0.22)$ and stages $2 \mathrm{~b}$ and $2 \mathrm{e}$ $(P=0.30)$ for females (Figure 4$)$.

3.3. Histology of Ovary Development. Six oocyte developmental stages could be distinguished from the histological analysis of ovaries (Figure 5), namely, oogonia (Oo), early primary oocytes (Ep), late primary oocytes (Lp), early vitellogenic oocytes (Ev), late vitellogenic oocytes (Lv), and postvitellogenic oocytes $(\mathrm{Pv})$, whose microscopic features are synthetically reported in Table 3. Post-vitellogenic oocytes, which have never been reported so far in A. foliacea, were found in some specimens macroscopically staged $2 \mathrm{~d}$ (mature) (Table 1). These oocytes had the same size and yolk inclusions as the late vitellogenic ones $(350-470 \mu \mathrm{m})$, but their 
TABLE 2: Length composition characterization of Aristaeomorpha foliacea according to the box plot approach, by stage, sex, and years combined.

\begin{tabular}{|c|c|c|c|c|c|c|c|c|c|}
\hline Sex & Stage & $n$ & Mean & Median & Minimum & Maximum & Lower quartile & Higher quartile & sd \\
\hline \multirow{6}{*}{ Females } & 1 & 1069 & 23.83 & 24 & 16 & 26 & 22 & 26 & 2.08 \\
\hline & $2 \mathrm{a}$ & 3835 & 31.93 & 31 & 27 & 40 & 29 & 34 & 3.97 \\
\hline & $2 \mathrm{~b}$ & 3507 & 48.78 & 49 & 41 & 67 & 44 & 53 & 5.61 \\
\hline & $2 c$ & 558 & 49.38 & 47 & 41 & 64 & 45 & 53.5 & 5.73 \\
\hline & $2 \mathrm{~d}$ & 849 & 51.80 & 51 & 41 & 66 & 46 & 57 & 6.35 \\
\hline & $2 e$ & 620 & 47.56 & 45 & 41 & 60 & 44 & 51 & 5.34 \\
\hline \multirow{4}{*}{ Males } & 1 & 16 & 19.25 & 19.5 & 18 & 20 & 19 & 20 & 0.86 \\
\hline & $2 \mathrm{a}$ & 363 & 23.18 & 23 & 21 & 24 & 23 & 24 & 0.92 \\
\hline & $2 b$ & 647 & 27.17 & 27 & 25 & 33 & 26 & 28 & 1.71 \\
\hline & $2 \mathrm{~d}$ & 9699 & 33.40 & 33 & 25 & 45 & 31 & 36 & 3.60 \\
\hline
\end{tabular}

TABLe 3: Histological description of oocyte developmental stages in Aristaeomorpha foliacea.

\begin{tabular}{|c|c|c|c|}
\hline & Oogenic stage & Size $(\mu \mathrm{m})$ & Histological description \\
\hline \multirow{7}{*}{ Oocytes } & Oogonia $(\mathrm{Og})$ & $<10$ & $\begin{array}{l}\text { Large, clear nucleus containing many strongly basophilic nucleoli, one of } \\
\text { which is more evident. Cytoplasm barely visible. }\end{array}$ \\
\hline & Early primary (Ep) & $15-25$ & $\begin{array}{l}\text { Large, clear nucleus containing chromatin clusters and filaments. } \\
\text { Cytoplasm barely visible. }\end{array}$ \\
\hline & Late primary (Lp) & $25-85$ & $\begin{array}{l}\text { Large, clear nucleus containing many peripheral nucleoli. Strongly } \\
\text { basophilic cytoplasm. }\end{array}$ \\
\hline & Early vitellogenic (Ev) & $90-300$ & $\begin{array}{l}\text { Rectangular in section. Round, central nucleus, with flattened nucleoli } \\
\text { leaned against the nuclear envelope. Cytoplasm filled with lipid vesicles. } \\
\text { Eosinophilic, yolk granules form a ring around the nucleus. }\end{array}$ \\
\hline & Late vitellogenic (Lv) & $200-350$ & $\begin{array}{l}\text { Rectangular in section. Small, central nucleus. Cytoplasm filled with lipid } \\
\text { vesicles and yolk granules. }\end{array}$ \\
\hline & Post-vitellogenic (Pv) & $350-470$ & $\begin{array}{l}\text { Nucleus no longer visible. Cytoplasm filled with yolk granules and lipid } \\
\text { vesicles. Slightly eosinophilic, columnar cristae protruding into the outer } \\
\text { cytoplasmic cortex. }\end{array}$ \\
\hline & Atresic (Ao) & - & As Lp oocytes, showing massive vacuolization of cytoplasm. \\
\hline
\end{tabular}

TABLE 4: Histological description of ovarian maturity stages in Aristaeomorpha foliacea, with their relative GSI (mean \pm s.d.).

\begin{tabular}{|c|c|c|c|}
\hline \multicolumn{3}{|c|}{ (MEDITS Instruction Manual v.5.0, 2008) } & GSI \\
\hline 1 & Immature & $\begin{array}{l}\text { Oogonia }(\mathrm{Og}) \text { and early primary oocytes }(\mathrm{Ep}) \text { scattered in the connective } \\
\text { stroma. Late primary oocytes (Lp) occasionally present. }\end{array}$ & $\begin{array}{l}0.11 \pm 0.08 \\
(n=11)\end{array}$ \\
\hline $2 \mathrm{a}$ & Virgin developing & $\begin{array}{l}\text { Germinative zone containing Oo and Ep. Maturative zone containing Lp, } \\
\text { organized into tubule-like structural units. }\end{array}$ & $\begin{array}{l}0.53 \pm 0.13 \\
(n=10)\end{array}$ \\
\hline $2 \mathrm{~b}$ & Recovering & The same as $2 \mathrm{a}$. & $\begin{array}{c}1.17 \pm 0.69 \\
(n=59)\end{array}$ \\
\hline $2 c$ & Maturing & $\begin{array}{l}\text { Maturative parenchyma containing a single batch of early vitellogenic } \\
\text { (Ev) oocytes, organized into tubule-like structural units. Germinative } \\
\text { islets populated by Oo and Ep oocytes. }\end{array}$ & $\begin{array}{l}5.07 \pm 1.64 \\
(n=14)\end{array}$ \\
\hline $2 \mathrm{~d}$ & Mature & $\begin{array}{l}\text { Maturative parenchyma containing late vitellogenic oocytes (Lv), piled up } \\
\text { in tubular units. The most advanced specimens contain post-vitellogenic } \\
\text { oocytes (Pv). Germinative islets populated by Oo and Ep oocytes. }\end{array}$ & $\begin{array}{l}9.29 \pm 2.51 \\
(n=11)\end{array}$ \\
\hline $2 \mathrm{e}$ & Resting & $\begin{array}{l}\text { Proliferation and hypertrophy of mesodermal cells lining tubular units. } \\
\text { The latter are populated by Lp oocytes at an initial stage of atresia (Ao), } \\
\text { among which some residual Pv oocyte could be detected. }\end{array}$ & $\begin{aligned} 2.17 & \pm 0.47 \\
(n & =9)\end{aligned}$ \\
\hline
\end{tabular}




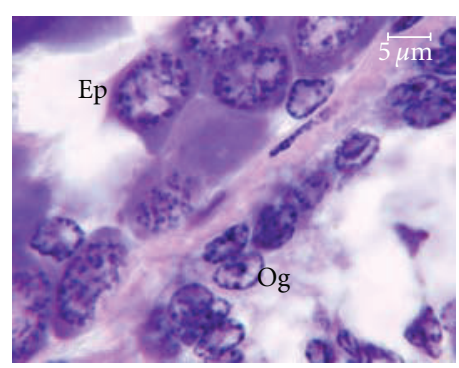

(a)

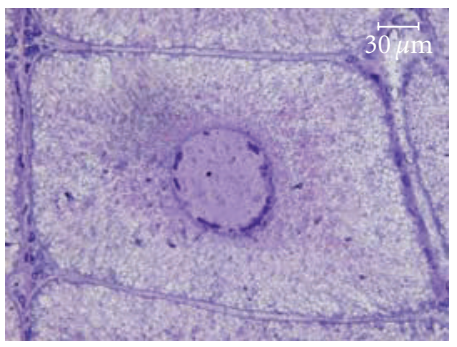

(c)

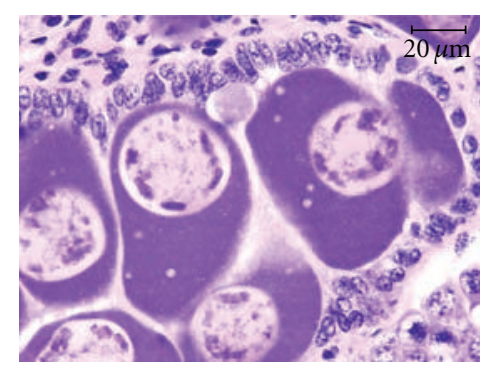

(b)

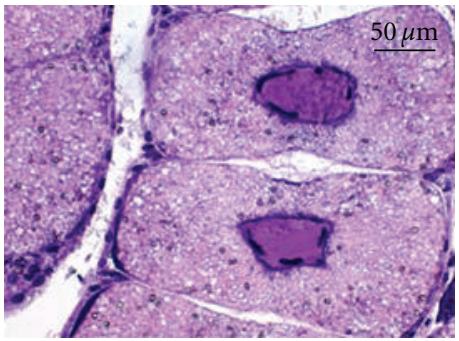

(d)

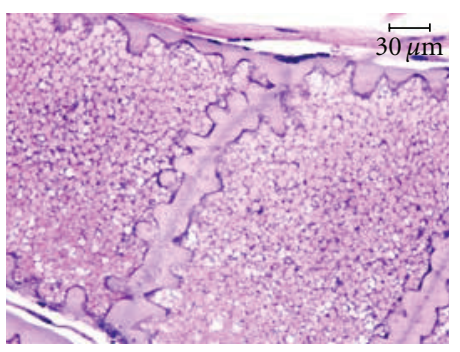

(e)

FIGURE 5: Oocyte developmental stages of Aristaeomorpha foliacea. (a) Oogonia (Og) and early primary stage (Ep); (b) late primary stage; (c) early vitellogenic stage; (d) late vitellogenic stage; (e) post-vitellogenic stage. (Haematoxylin-eosin.)

nucleus was not visible, and they displayed slightly eosinophilic, columnar cristae protruding into the outer cytoplasmic cortex (Figure 5(e)), strongly resembling penaeid cortical rods $[24,25]$. For these reasons, such oocytes were considered to have achieved vitellogenesis and started final maturation prior to ovulation. Another type of oocyte was found, that is, Lp oocytes, showing massive vacuolization of cytoplasm (Figure 6(e)). As these oocytes occurred only in spent specimens, they are likely to be abortive oocytes at an initial stage of atresia (Ao), destined to be resorbed.

The histological description of macroscopic maturity stages employed in MEDITS surveys is reported in Table 4 and Figure 6. Immature ovaries (stage 1) showed an even connective stroma populated by oogonia, early primary oocytes, and occasional late primary oocytes. In all other specimens, the ovarian parenchyma consisted of germinal and maturative zones, the former containing oogonia and early primary oocytes and the latter containing later oocyte stages. Stage $2 \mathrm{a}$ (virgin developing) and $2 \mathrm{~b}$ (recovering) ovaries were histologically identical, with Lp oocytes as the most advanced developmental stage. As ovary maturation proceeded, developing oocytes occupied most of the ovarian parenchyma, leaving only small germinative islets of resting oocytes interspersed between them. Oocyte development in the maturative parenchyma occurred in a synchronous way, as indicated by a single batch of oocytes at the early vitellogenic $(\mathrm{Ev})$ stage in maturing (2c) ovaries and a single batch of oocytes at the late vitellogenic $(\mathrm{Lv})$ or post-vitellogenic $(\mathrm{Pv})$ stage in mature (2d) ovaries. Resting (2e) ovaries were characterized by hyperaemia of ovarian stroma and marked proliferation and hypertrophy of mesodermal (somatic) cells lining tubular units. The latter were populated by atresic oocytes (Ao), among which some residual Pv oocytes could be detected.

The lowest and highest GSI values of females examined in the present study were 0.006 (stage 1 specimen with $\mathrm{CL}=$ $25 \mathrm{~mm}$ ) and 13.87 (stage $2 \mathrm{~d}$ specimen with $\mathrm{CL}=46 \mathrm{~mm}$ ), respectively. The mean GSI values for each maturity stage are reported in Table 4.

\section{Discussion}

The giant red shrimp, Aristaeomorpha foliacea, is among the most prized demersal resources exploited by deep-sea fishery in the southern Tyrrhenian Sea. The importance of this resource to Mediterranean fisheries is supported by the results on the biology and ecology of this species, obtained from more than twenty years of trawl survey programmes 


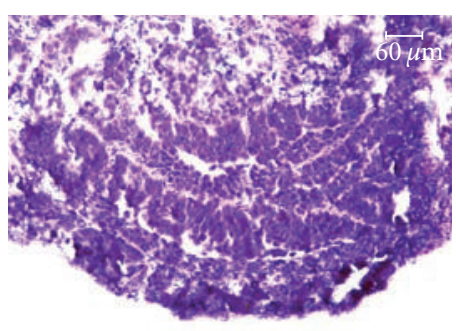

(a)

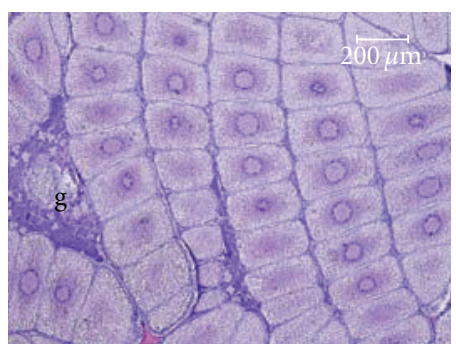

(c)

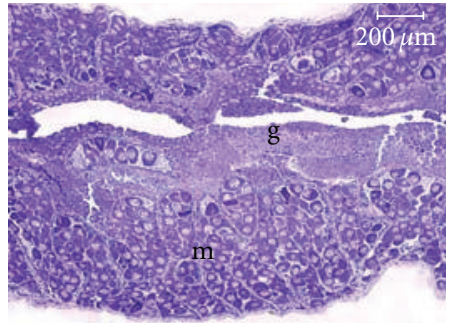

(b)

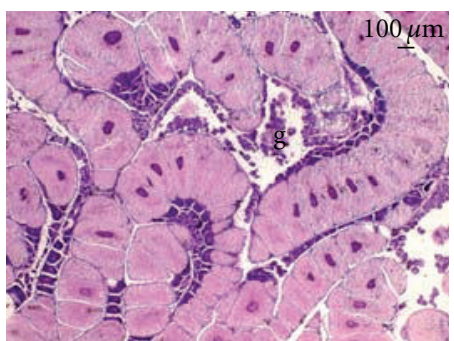

(d)

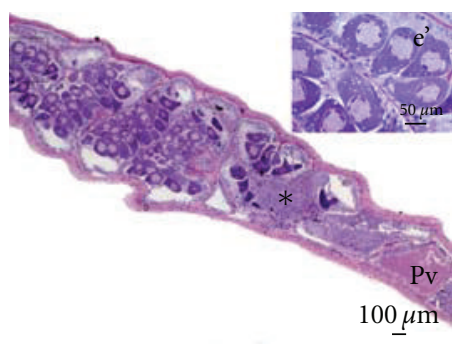

(e)

Figure 6: Ovarian maturity stages of Aristaeomorpha foliacea (haematoxylin-eosin). (a) Immature ovary (stage 1); (b) recovering ovary (stage $2 \mathrm{~b}$ ), showing distinct germinative $(\mathrm{g})$ and maturative $(\mathrm{m})$ zones, the latter populated by late primary oocytes organized into tubulelike structural units. (c) Maturing ovary (stage 2c) populated by early vitellogenic oocytes, among which small germinative islets (g) can be seen. (d) Mature ovary (stage 2d) populated by late vitellogenic oocytes creating a mosaic structure. g: germinative islets. (e) Spent ovary (stage 2e) containing a residual post-vitellogenic oocyte $(\mathrm{Pv})$, besides degenerating late primary oocytes displaying severe vacuolization of the cytoplasm (e'). Proliferation and hypertrophy of mesodermal cells (asterisk) are also evident.

(i.e., GRUND, Valutazione delle Risorse Demersali, and MEDITS, International Bottom Trawl Survey in the Mediterranean).

The reproductive season of $A$. foliacea in the studied area, as indicated by presence of mature females (JuneSeptember), is comparable with that one reported along the Sardinian coasts [26], but it is shorter than in northern areas of western Mediterranean $[16,20]$, as well as than in eastern Mediterranean $[18,19]$. On the other hand, the occurrence of mature males $(\geq 50 \%)$ in all months, suggesting no evidence of a seasonal maturity cycle, seems to be a constant reproductive feature of $A$. foliacea all over the Mediterranean. Such a protracted reproductive capacity of males could be related to mating activity. In fact, inseminated females occurred all year round, as in all Mediterranean populations studied [1619]. Inseminated females were staged $2 \mathrm{~b}$ through $2 \mathrm{e}$, suggesting that mating may take place also after oviposition. On the other hand, immature (stage 1) and developing virgins (stage $2 \mathrm{a}$ ) were never inseminated, suggesting that ovary maturation is triggered by mating. In other areas, resting females bearing spermatophores were reported in proportions ranging from 6\% (west Pacific) [22] to 60\% (eastern Mediterranean) [19]. However, while ovary maturation has been reported to follow mating by four months in eastern Mediterranean [19], it would seem that it occurs within one month from mating during the first reproductive cycle in our western Mediterranean population. The lower proportion of mature males from April to September was not paralleled by a decreased number of inseminated females in the same months, suggesting the possibility that males are able to mate with multiple females, as hypothesized in Aristeus antennatus [19].

The fully mature female minimum size of $A$. foliacea in the present study $(41 \mathrm{~mm} \mathrm{CL})$ is by far the largest ever recorded in the Mediterranean (27-40 mm CL), confirming a westward gradient in minimum size at maturity [18]. The size at maturity stage analysis, made on all combined months, indicated, for both sexes, a satisfactory resolution capability of the adopted scale.

A reliable maturity staging is needed for a correct evaluation of spawning-stock biomass (SSB) (i.e., the biomass of reproducing individuals in a population), which is crucial in 
stock assessment studies. In fact, it has been demonstrated that macroscopic staging of the gonads may lead to overestimating SSB by up to $35 \%$ in fish [27]. For this reason, histological analysis of gonads is recommended to validate macroscopic observations, as well as to standardize criteria for comparing maturity data from different populations [28]. This is particularly true for crustacean species, whose reproductive features are less documented than those of fish.

The GSI values of the different maturity stages were similar to those from other studies, except for the immature stage, which was considerably lower than those reported not only in Taiwan and eastern Mediterranean $[19,22]$, but also in a population of western Mediterranean [21].

The histological observation of ovaries in A. foliacea allowed us to detect a novel oogenic stage, which had not been described in previous studies [21-23], namely, the postvitellogenic stage. Such stage was characterized by the presence of cortical cristae, resembling the "cortical rods" of penaeid shrimps $[29,30]$. Cortical rods are formed after completion of yolk accumulation and are involved in the cortical reaction initiated by contact with sea water [29], by forming a jelly layer around the egg, preventing polyspermy. In penaeid oocytes, which possess a vitelline envelope, cortical rods develop outside the oocyte plasma membrane but under the vitelline membrane [30]. In our study, light microscopy showed that cortical cristae are housed in crypts formed by invaginations of the oolemma, and therefore they are extracellular, as cortical rods.

Ovary maturation in A. foliacea involved a large batch of oocytes developing synchronously inside tubular units, with resting oocytes remaining in the germinative islets between them. Prespawning ovaries were almost completely filled with post-vitellogenic oocytes, to be released at the next spawning, while oogonia and oocytes at the previtellogenic stages remained in the ovary, with the most advanced of them (Lp oocytes) undergoing degeneration after spawning. Such features are indicative of a group-synchronous ovarian developmental pattern [31] and strongly suggest that $A$. foliacea has a determinate fecundity, that is, fecundity is fixed before the onset of spawning [32]. It is likely that A. foliacea is a total spawner, that is, all yolked oocytes are released in a unique spawning event during each reproductive season, as $A$. antennatus [33].

For the first time, the histological features of spent ovaries were described. In these ovaries, which was found in August and September, the architecture of ovarian stroma appeared modified, by proliferation and hypertrophy of mesodermal cells, accompanied by hyperaemia, while pre-vitellogenic oocytes (Lp stage) left in the ovary after spawning of mature eggs displayed severe vacuolization of the cytoplasm. This is likely to be an initial phase of atresia, suggesting future resorption of these oocytes, while the oocytes destined to develop in the next reproductive season may be recruited from the batch of early primary oocytes left in the ovary. The occurrence of the "spent" stage in A. foliacea has been debated, since the first observations [21], which lead [22] to hypothesize that females may die after spawning, or move to waters deeper than $600 \mathrm{~m}$, where they may be missed by trawlers. On the other hand, [19] reported 16\% spent specimens from
July, consistently with the 1-month-advanced spawning in that area. Our results suggest that $A$. foliacea starts reorganizing the ovary soon after spawning, and this process lasts about 2 months, after which a recovering ovary with no signs of previous spawning or oocyte resorption is found.

On the basis of histological observations, a reduction of the macroscopic maturity stages employed in MEDITS survey to five (namely, (1) immature, (2) developing/recovering, (3) maturing, (4) mature, and (5) spent) could be advisable, as proposed in the framework of the Workshop on crustacean (Aristeus antennatus, Aristaeomorpha foliacea, Parapenaeus longirostris, Nephrops norvegicus) maturity stages (WKMSC) held in Messina (Italy) in 2009 [28].

\section{References}

[1] M.L. Bianchini and S. Ragonese, "Life cycles and fisheries of the deep-water red shrimps Aristaeomorpha foliacea and Aristeus antennatus," in Proceedings of the International Workshop Held in the Istituto di Tecnologia della Pesca e del Pescato, vol. 3, p. 88, Mazara del Vallo, Italy, April 1994.

[2] I. Pérez Farfante and B. Kensley, Penaeoid and Sergestoid Shrimps and Prawns of the World: Keys and Diagnoses for the Families and Genera, vol. 175, Mémoirs du Muséum Nationale d'Histoire Naturelle, Paris, France, 1997.

[3] IREPA Istituto Ricerche Economiche per la Pesca, Osservatorio Economico Sulle Strutture Produttive Della Pesca Marittima in Italia 2008, Collana Irepa Ricerche, Franco Angeli Edizioni, Milan, Italy, 2008.

[4] A. Brian, "La biologia del fondo a 'Scampi' nel Mar ligure," in 5.Aristaeomorpha, Aristeus ed altri Macruri reptanti Bollettino dei Musei di Zoologia e Anatomia Comparata della R, vol. 11, pp. 1-6, Università di Genova, 1931.

[5] L.B. Holthuis, Shrimps and Lobsters of the World: An Annotated Catalogue of Species of Interest to Fisheries Volume 1 of FAO Species Catalogue, vol. 125, FAO Fisheries Synopsis, 1980.

[6] A. Cau, A. M. Deiana, and M. Mura, "Ecological observations on Aristaeomorpha foliacea (Risso, 1827) (Decapoda, Penaeidae) in the mid-Western Mediterranean Sea," Investigacion Pesquera, vol. 51, no. 1, p. 456, 1987.

[7] S. Ragonese, M. L. Bianchini, and V. F. Gallucci, "Growth and mortality of the red shrimp Aristaeomorpha foliacea in the Sicilian Channel (Mediterranean Sea)," Crustaceana, vol. 67, no. 3, pp. 348-361, 1994.

[8] M. T. Spedicato, G. Lembo, P. Carbonara, and T. Silecchia, "Biological parameters and dynamics of Aristaeomorpha foliacea in Southern Tyrrhenian Sea," in Life Cycles and Fisheries of the Deep-Water Red Shrimps Aristaeomorpha Foliacea and Aristeus Antennatus, M. L. Bianchini and S. Ragonese, Eds., Proceedings of the International Workshop Held in the Istituto di Tecnologia della Pesca e del Pescato, pp. 35-36, Mazara del Vallo, Italy, 1994.

[9] S. Ragonese, "Geographical distribution of Aristaeomorpha foliacea (Crustacea, Aristeidae) in the Sicilian Channel (Mediterranean Sea)," in Proceedings of the ICES Marine Science Symposium, vol. 199, pp. 183-188, 1995.

[10] S. Ragonese and M. L. Bianchini, "Size at sexual maturity in red shrimp females, Aristaeomorpha foliacea, from the Sicilian Channel (Mediterranean Sea)," Crustaceana, vol. 68, no. 1, pp. 73-82, 1995.

[11] A. Matarrese, G. D’onghia, M. DE Florio, M. Panza, and G. Costantino, "Recenti acquisizioni sulla distribuzione batimetrica di Aristaeomorpha foliacea ed Aristeus antennatus 
(Crustacea, Decapoda) nel Mar Ionio," Biologia Marina Mediterranea, vol. 2, pp. 299-300, 1995.

[12] A. Matarrese, G. D’onghia, A. Tursi, and P. Maiorano, "Vulnerabilità e resilienza di Aristaeomorpha foliacea (Risso, 1827) e Aristeus antennatus (Risso, 1816) (Crostacei, Decapodi) nel Mar Ionio," in Proceedings of the 18th Congresso Società Italiana di Ecologia, vol. 71, pp. 535-538, 1997.

[13] G. D'onghia, P. Maiorano, A. Matarrese, and A. Tursi, "Distribution, biology, and population dynamics of Aristaeomorpha foliacea (Risso, 1827) (Decapoda, Natantia, Aristeidae) in the north-western Ionian Sea (Mediterranean Sea)," Crustaceana, vol. 71, no. 5, pp. 518-544, 1998.

[14] M. Mura, S. Campisi, and A. Cau, "Osservazioni sulla biologia riproduttiva negli aristeidi demersali del Mediterraneo Centro-Occidentale," Oebalia, supplement 17, pp. 75-80, 1992.

[15] M. Mori, F. Biagi, and S. DE Ranieri, "Reproductive biology of Aristaeomorpha foliacea in the Southern Tuscany archipelago (Central Tyrrhenian Sea)," in Life Cycles and Fisheries of the Deep-water Red Shrimps Aristaeomorpha foliacea and Aristeus antennatus, M. L. Bianchini and S. Ragonese, Eds., vol. 3 of Proceedings of the International Workshop Held in the Istituto di Tecnologia della Pesca e del Pescato, pp. 31-32, Mazara del Vallo, Italy, 1994.

[16] P. Belcari, C. Viva, M. Mori, and S. De Ranieri, "Fishery and biology of Aristaeomorpha foliacea (Risso, 1827) (Crustacea: Decapoda) in the northern Tyrrhenian Sea (Western Mediterranean)," Journal of Northwest Atlantic Fishery Science, vol. 31, pp. 195-204, 2003.

[17] C. Papaconstantinou and K. Kapiris, "The biology of the giant red shrimp (Aristaeomorpha foliacea) at an unexploited fishing ground in the Greek Ionian Sea," Fisheries Research, vol. 62, no. 1, pp. 37-51, 2003.

[18] C. Y. Politou, K. Kapiris, P. Maiorano, F. Capezzuto, and J. Dokos, "Deep-sea Mediterranean biology: the case of Aristaeomorpha foliacea (Risso, 1827) (Crustacea: Decapoda: Aristeidae)," Scientia Marina, vol. 68, no. 3, pp. 129-139, 2004.

[19] K. Kapiris and M. Thessalou-legaki, "Comparative reproduction aspects of the deep-water shrimps Aristaeomorpha foliacea and Aristeus antennatus (Decapoda, Aristeidae) in the Greek Ionian Sea (Eastern Mediterranean)," Journal of Zoology Article, vol. 2009, Article ID 979512, 9 pages, 2009.

[20] L. Orsi Relini and M. Semeria, "Oogenesis and fecundity in bathyal penaeid prawns, Aristeus antennatus and Aristaeomorpha foliacea," Rapport de la Commission Internationale pour la Exploration Scientifique de la Mer Mediterranée, 1983.

[21] D. Levi and M. Vacchi, "Macroscopic scale for simple and rapid determination of sexual maturity in Aristaeomorpha foliacea (Risso, 1826) (Decapoda: Penaeidae)," Journal of Crustacean, vol. 8, no. 4, pp. 532-538, 1988.

[22] H. C. Kao, T. Y. Chan, and H. P. Yu, "Ovary development of the deep-water shrimp Aristaeomorpha foliacea (Risso, 1826) (Crustacea: Decapoda: Aristeidae) from Taiwan," Zoological Studies, vol. 38, no. 4, pp. 373-378, 1999.

[23] S. Desantis, M. Labate, P. Maiorano, A. Tursi, G. M. Labate, and M. Ciccarelli, "A histochemical and ultrastructural study of oogenesis in Aristaeomorpha foliacea (Risso, 1827)," Hydrobiologia, vol. 449, pp. 253-259, 2001.

[24] K. Yamano, G. F. Qiu, and T. Unuma, "Molecular cloning and ovarian expression profiles of thrombospondin, a major component of cortical rods in mature oocytes of penaeid shrimp, Marsupenaeus japonicus," Biology of Reproduction, vol. 70, no. 6, pp. 1670-1678, 2004.

[25] S. Peixoto, G. Coman, S. Arnold, P. Crocos, and N. Preston, "Histological examination of final oocyte maturation and atresia in wild and domesticated Penaeus monodon (Fabricius) broodstock," Aquaculture Research, vol. 36, no. 7, pp. 666-673, 2005.

[26] M. C. Follesa, D. Cuccu, M. Murenu, A. Sabatini, and A. Cau, "Aspetti riproduttivi negli Aristeidi, Aristaemorpha foliacea (Risso, 1827) e Aristeus antennatus (Risso, 1816), della classe di età $0^{+}$e $1^{+}$," Biologia Marina Mediterranea, vol. 5, no. 2, pp. 232-238, 1998.

[27] F. Vitale, H. Svedäng, and M. Cardinale, "Histological analysis invalidates macroscopically determined maturity ogives of the Kattegat cod (Gadus morhua) and suggests new proxies for estimating maturity status of individual fish," ICES Journal of Marine Science, vol. 63, no. 3, pp. 485-492, 2006.

[28] ICES, "Aristeus antennatus, Aristaeomorpha foliacea, Parapenaeus longirostris, Nephrops norvegicus maturity stages," in Proceedings of the Workshop on Crustaceans, vol. 46 of ICES documents CM 2009/ACOM, p. 77, ICES, 2010.

[29] W. H. Clark, J. W. Lynn, A. I. Yudin, and H. O. Persyn, "Morphology of the cortical region in the eggs of Penaeus atzecus," Biological Bulletin, vol. 158, pp. 175-186, 1980.

[30] W. H. Clark Jr., A. I. Yudin, J. W. Lunn, F. J. Griffin, and M. C. Pillai, "Jellymlayer formation in penaeoidean shrimp eggs," Biological Bulletin, vol. 178, pp. 295-299, 1990.

[31] R. A. Wallace and K. Selman, "Cellular and dynamic aspects of Oocyte growth in Teleosts," Integrative and Comparative Biology, vol. 21, no. 2, pp. 325-343, 1981.

[32] J. R. Hunter, B. J. Macewicz, N. Chyan-Huei Lo, and C. A. Kimbrell, "Fecundity, spawning, and maturity of female Dover sole Microstomus pacificus, with an evaluation of assumptions and precision," Fishery Bulletin, vol. 90, no. 1, pp. 101-128, 1992.

[33] A. Carbonell, A. Grau, V. Lauronce, and C. Gómez, "Ovary development of the red shrimp, Aristeus antennatus (Risso, 1816) from the northwestern Mediterranean Sea," Crustaceana, vol. 79, no. 6, pp. 727-743, 2006. 

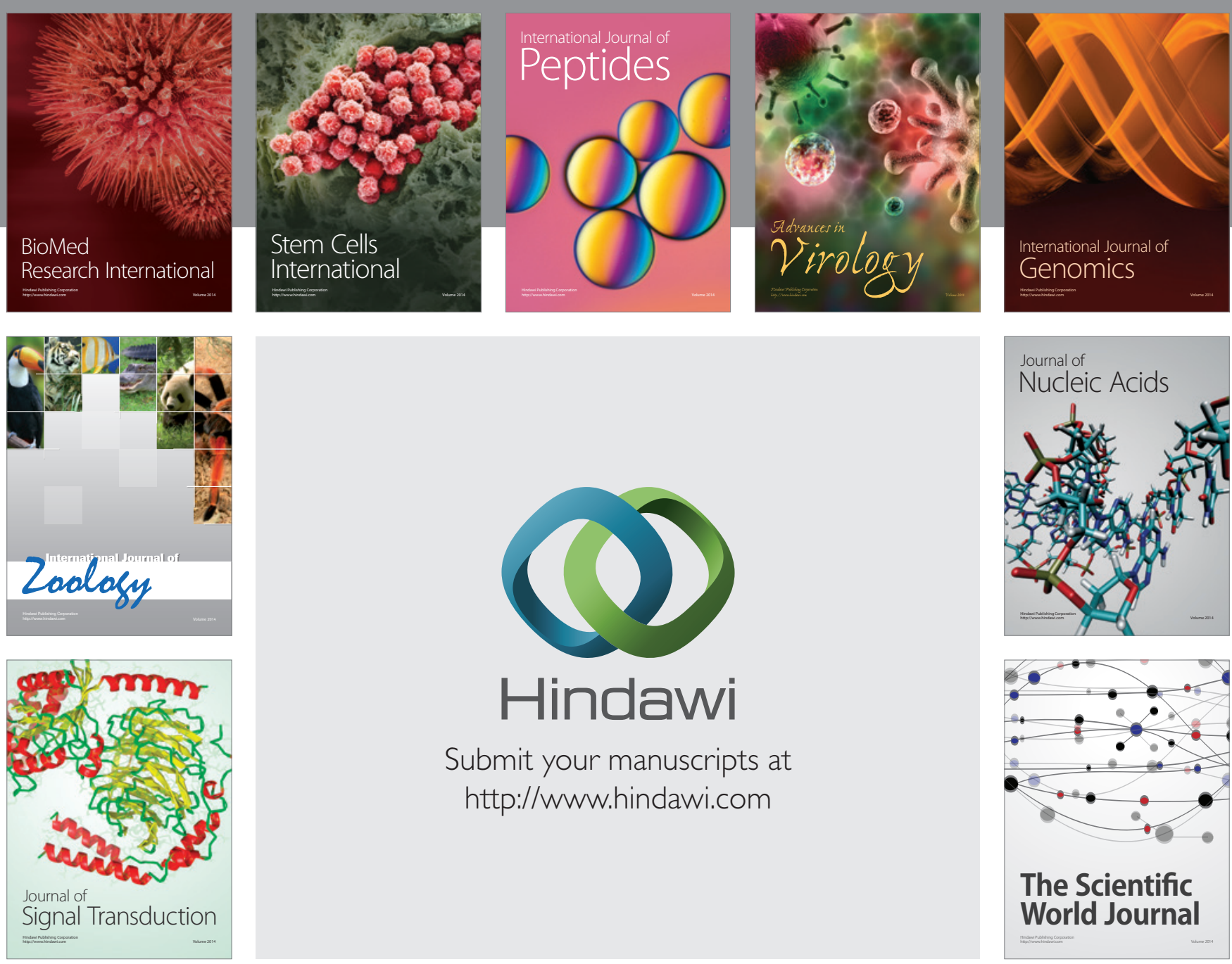

Submit your manuscripts at

http://www.hindawi.com
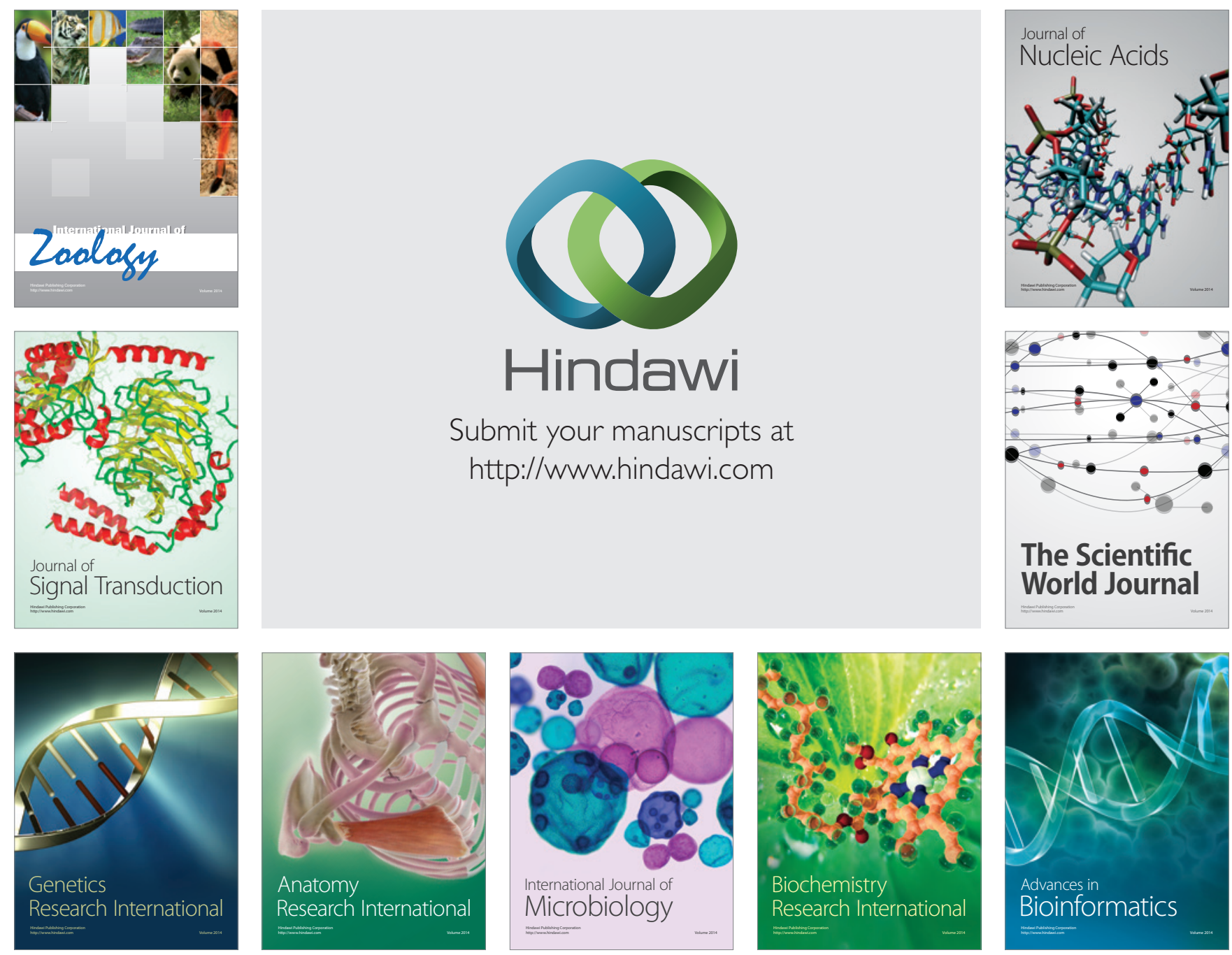

The Scientific World Journal
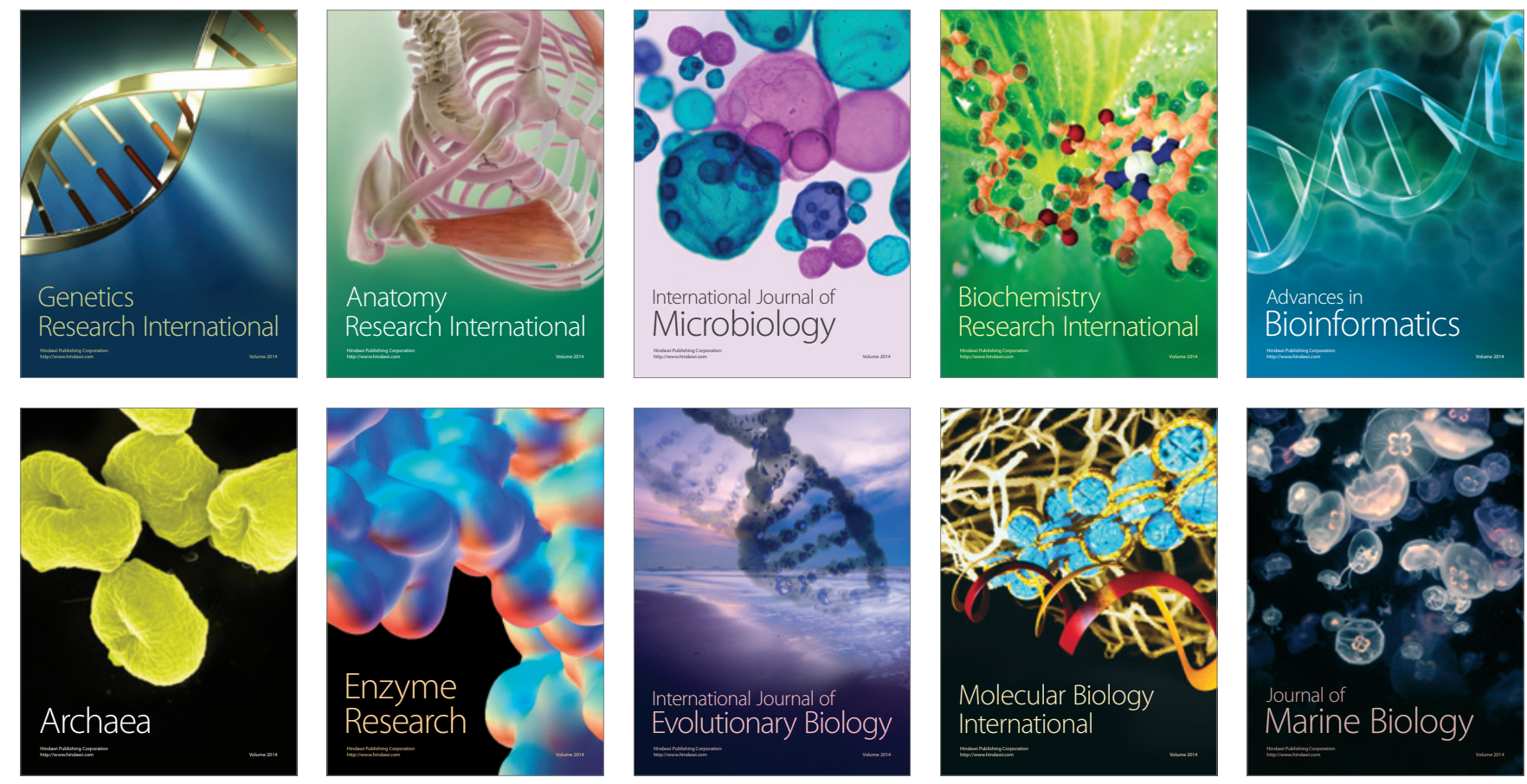